\title{
Corrigendum: Oxygen, gastrin-releasing peptide, and pediatric lung disease: life in the balance
}

\author{
Mary E. Sunday* \\ Department of Pathology, Duke University Medical Center, Durham, NC, USA \\ ${ }^{*}$ Correspondence: mary.sunday@duke.edu \\ Edited and reviewed by: \\ Heber C. Nielsen, Tufts Medical Center and Tufts School of Medicine, USA
}

Keywords: correction, ozone, gastrin-releasing peptide, lung, injury

\section{A corrigendum on}

Oxygen, gastrin-releasing peptide, and pediatric lung disease: life in the balance by Sunday ME. Front Pediatr (2014) 2:72. doi:10.3389/fped.2014.00072

Reference \# 7 needs to be corrected to: Mary Sunday and Barbara Theriot, unpublished data. We have recently determined that most of the ovalbumin data in the article is unreliable. However, we have successfully validated the ozone data in additional experiments independent of those included in the article, which is the basis for the citation.

Conflict of Interest Statement: The author declares that the research was conducted in the absence of any commercial or financial relationships that could be construed as a potential conflict of interest.

Received: 13 August 2014; accepted: 07 September 2014; published online: 02 October 2014.
Citation: Sunday ME (2014) Corrigendum: Oxygen, gastrin-releasing peptide, and pediatric lung disease: life in the balance. Front. Pediatr. 2:102. doi: 10.3389/fped.2014.00102

This article was submitted to Neonatology, a section of the journal Frontiers in Pediatrics.

Copyright (c) 2014 Sunday. This is an open-access article distributed under the terms of the Creative Commons Attribution License (CC BY). The use, distribution or reproduction in other forums is permitted, provided the original author(s) or licensor are credited and that the original publication in this journal is cited, in accordance with accepted academic practice. No use, distribution or reproduction is permitted which does not comply with these terms. 